\title{
Chronic hepatitis C virus infection: Prevalence of extrahepatic manifestations and association with cryoglobulinemia in Bulgarian patients
}

\author{
Diana V Stefanova-Petrova, Anelia H Tzvetanska, Elisaveta J Naumova, Anastasia P Mihailova, Evgenii A Hadjiev, \\ Rumiana P Dikova, Mircho I Vukov, Konstantin G Tchernev
}

\begin{abstract}
Diana V Stefanova-Petrova, Konstantin G Tchernev, Department of Internal Diseases and Gastroenterology, University Hospital Alexandrovska, Sofia 1431, Bulgaria

Anelia H Tzvetanska, Viral Laboratory, University Pediatric Hospital, Sofia 1431, Bulgaria

Elisaveta J Naumova, Anastasia P Mihailova, Central Laboratory of Immunology, University Hospital Alexandrovska, Sofia 1431, Bulgaria

Evgenii A Hadjiev, Department of Hematology, University Hospital Alexandrovska, Sofia 1431, Bulgaria

Rumiana P Dikova, Department of Pathology, University Hospital Alexandrovka, Sofia 1431, Bulgaria

Mircho I Vukov, National Centre for Health Information, Sofia 1431, Bulgaria

Correspondence to: Dr. Diana V Stefanova-Petrova, Department of Internal Diseases and Gastroenterology, University Hospital Alexandrovska, 1, Georgi Sofiiski Str, Sofia 1431, Bulgaria.d.petrova.stefanova@gmail.com

Telephone: +359-2-9478670 Fax: +359-2-9230654

Received: August 26, 2007 Revised: September 28, 2007
\end{abstract}

\begin{abstract}
AIM: To assess the prevalence of extrahepatic manifestations in Bulgarian patients with chronic hepatitis $\mathrm{C}$ virus (HCV) infection and identify the clinical and biological manifestations associated with cryoglobulinemia.
\end{abstract}

METHODS: The medical records of 136 chronically infected HCV patients were reviewed to assess the prevalence of extrahepatic manifestations. Association between cryoglobulin-positivity and other manifestations were identified using $\chi^{2}$ and Fisher's exact test. Risk factors for the presence of extrahepatic manifestations were assessed by logistic regression analysis.

RESULTS: Seventy six percent (104/136) of the patients had at least one extrahepatic manifestation. Clinical manifestations included fatigue $(59.6 \%)$, kidney impairment (25.0\%), type 2 diabetes $(22.8 \%)$, paresthesia $(19.9 \%)$, arthralgia $(18.4 \%)$, palpable purpura $(17.6 \%)$, lymphadenopathy $(16.2 \%)$, pulmonary fibrosis $(15.4 \%)$, thyroid dysfunction (14.7\%), Raynaud's phenomenon $(11.8 \%)$, B-cell lymphoma $(8.8 \%)$, sicca syndrome $(6.6 \%)$, and lichen planus $(5.9 \%)$. The biological manifestations included cryoglobulin production (37.5\%), thrombocytopenia $(31.6 \%)$, and autoantibodies: anti-nuclear (18.4\%), anti-smooth muscle (16.9\%), anti-neutrophil cytoplasm (13.2\%) and anti-cardiolipin (8.8\%). All extrahepatic manifestations showed an association with cryoglobulin-positivity, with the exception of thyroid dysfunction, sicca syndrome, and lichen planus. Risks factors for the presence of extrahepatic manifestations (univariate analysis) were: age $\geqslant 60$ years, female gender, virus transmission by blood transfusions, longstanding infection ( $\geqslant 20$ years), and extensive liver fibrosis. The most significant risks factors (multivariate analysis) were longstanding infection and extensive liver fibrosis.

CONCLUSION: We observed a high prevalence of extrahepatic manifestations in patients with chronic HCV infection. Most of these manifestations were associated with impaired lymphoproliferation and cryoglobulin production. Longstanding infection and extensive liver fibrosis were significant risk factors for the presence of extrahepatic manifestations in HCV patients.

(c) 2007 WJG. All rights reserved.

Key words: Hepatitis C; Liver cirrhosis; Extrahepatic manifestations

Stefanova-Petrova DV, Tzvetanska AH, Naumova EJ, Mihailova AP, Hadjiev EA, Dikova RP, Vukov MI, Tchernev KG. Chronic hepatitis $C$ virus infection: Prevalence of extrahepatic manifestations and association with cryoglobulinemia in Bulgarian patients. World $\mathrm{J}$ Gastroenterol 2007; 13(48): 6518-6528

http://www.wjgnet.com/1007-9327/13/6518.asp

\section{INTRODUCTION}

Hepatitis $\mathrm{C}$ virus (HCV) is associated with a wide spectrum of clinical and biological extrahepatic manifestations ${ }^{[1-3]}$. In chronically infected patients, the virus can trigger an impairment in lymphoproliferation with cryoglobulin production ${ }^{[3]}$. Mixed cryoglobulinemia with its complications (skin, neurological, renal, and rheumatologic) is the most significant extrahepatic manifestation of $\mathrm{HCV}$ 
infection ${ }^{[4,5]}$. Mixed cryoglobulinemia can evolve into B-cell lymphoma in up to $10 \%$ of the patien ${ }^{[6,7]}$.

Various non-organ specific auto-antibodies, present in low titers, are noted during the course of chronic HCV infection ${ }^{[8,9]}$, but they do not influence the clinical profile of the disease ${ }^{[10]}$. Chronic HCV infection has been linked to two skin disorders, porphyria cutanea tarda and lichen planus, particularly with the involvement of the oral cavity ${ }^{[11,12]}$. Other possible HCV-associated diseases are type 2 diabetes mellitus ${ }^{[13]}$, thrombocytopenia ${ }^{[14]}$ and pulmonary fibrosis ${ }^{[15]}$. The sicca syndrome, although different from the typical Sjogren's syndrome, also appears to be associated with hepatitis $C$ virus infection ${ }^{[16,17]}$.

It is unclear whether HCV plays a pathogenic role in the development of thyroid dysfunction ${ }^{[18]}$. It is possible, that this extrahepatic manifestation of HCV is related to treatment with interferon rather than the virus ${ }^{[19]}$.

The most common risk factors associated with extrahepatic manifestations of HCV infection are older age, female sex, and extensive liver fibrosis ${ }^{[8]}$. Several reports from different parts of the world suggest that hepatitis $\mathrm{C}$ virus affects not only the liver, but other tissues, organs and systems as well. Lymphoproliferative disorders, triggered by the virus, are the most significant extrahepatic manifestations in South-Eastern Europe, where Bulgaria is located.

The aim of the present study was to determine the prevalence of various extrahepatic manifestations of chronic HCV infection in our country, to analyze which extrahepatic manifestations are associated with impaired lymphoproliferation and cryoglobulin production, and to identify which patients are at greater risk of developing extrahepatic manifestations.

In our clinical practice, several patients present with extrahepatic manifestations even in the absence of a clearly defined clinical picture of hepatic illness. It is important to recognize these manifestations in order to make an early diagnosis and to initiate therapy in a timely manner.

\section{MATERIALS AND METHODS}

\section{Patients}

We included 136 Bulgarian patients who were referred to the Department of Internal Diseases and Gastroenterology of the University Hospital Alexandrovska during the period from 1996 to 2004. The main reason for patient referral was elevated liver enzymes. The diagnosis of $\mathrm{HCV}$ infection was made by the presence of anti-HCV antibodies (third generation ELISA) and a positive test for HCV-RNA (Cobas Amplicor HCV Monitor Test, v. 2.0, Roche Diagnostics). HCV genotypes were identified by direct sequence analysis (Immunogenetics, Belgium) in 60 patients ${ }^{[20]}$. HBsAg and HIV positive patients were not included in the study. Liver biopsy was performed in all patients. The data was collected before the patients were started on any specific treatment.

\section{Methods}

Patient records were reviewed to assess the presence of the following clinical manifestations: fatigue, arthralgia,
Raynaud's phenomenon, palpable purpura, paresthesia, renal impairment (proteinuria, creatinine above the upper normal limit, and hypertension), sicca syndrome (mouth and eyes), thyroid dysfunction (TSH level below or above the normal range of $0.31-5.00 \mathrm{mU} / \mathrm{L}$ ), lichen planus (skin and oral lesions), type 2 diabetes mellitus (hyperglycemia, treated by hypoglycemic drugs), pulmonary fibrosis (Xray examination), lymphadenopathy, and lymphoma. The enlargement of peripheral lymph nodes was detected by palpation. The enlargement of mediastinal lymph nodes was detected by X-ray examination, and abdominal lymphadenopathy was detected by abdominal ultrasonography. Chest X-ray and abdominal ultrasonography were obligatory exams carried out routinely in all patients admitted to the hospital. Lymph node enlargement was confirmed by computerized tomography. The diagnosis of lymphoma was based on morphologic evaluation of lymph node tissue in the patients with co-existing peripheral lymphadenopathy, and by bone marrow biopsy. Histological analysis of the enlarged mediastinal and/or abdominal lymph nodes was not performed because patients refused to provide informed consent for invasive diagnostic surgical procedures.

Biological data obtained from for each patient included the presence or absence of cryoglobulins, thrombocytopenia, and auto-antibodies: anti-nuclear (ANA), anti-smooth muscle (ASMA), anti-neutrophil cytoplasm (ANCA), and anti-cardiolipin (ACL). The platelet count was obtained from the patients' files. Thrombocytopenia was defined as platelet count $\leqslant$ $110.10^{\circ} / \mathrm{L}$. Cryoglobulins were detected by the Winfield method ${ }^{[21]}$. Twenty milliliters of venous blood was obtained from each patient in a pre-warmed $\left(37^{\circ} \mathrm{C}\right)$ syringe, allowed to clot at $37^{\circ} \mathrm{C}$ and the serum was separated by centrifugation. The supernatant was incubated at $4^{\circ} \mathrm{C}$ for $8 \mathrm{~d}$ and examined daily for cryoprecipitate. Indirect immunofluorescence was used for the detection of ANA, ASMA, and ANCA (IFA/ Binding Site). A positive test for ANA and ASMA was defined as a titer $\geqslant 1 / 40$, and for ANCA $\geqslant 1 / 20$. Anticardiolipin antibodies (ACL-IgG and ACL-IgM) were detected by ELISA (Orgentec).

The following demographic and epidemiologic data was collected: age (less or $\geqslant 60$ years), sex, the suspected duration of the infection (less or $\geqslant 20$ years), an alcohol intake (less or $\geqslant 50 \mathrm{~g} / \mathrm{d}$ ), and the mode of infection. Questions regarding the most relevant identifiable HCV risks factors were asked, including transfusion of blood and blood products, intravenous drug use, surgical procedures, dental manipulation associated with bleeding, and needle stick injury in health workers. In patients with a past history of transfusions of blood and blood products, it was assumed that HCV infection was caused by contaminated blood and blood products.

The histological abnormalities in liver biopsy specimens, obtained blindly (Hepafix $1.4 \mathrm{~mm}$, B. Braun, Germany), were scored according to the METAVIR system $^{[22]}$. Each liver biopsy sample was assessed for the stage of fibrosis and grade of histological activity. Liver fibrosis was staged on a scale of $0-4$, where $0=$ no fibrosis, 1 - portal fibrosis without septa, 2 = few septa, 
Table 1 Prevalence of clinical and biological extrahepatic manifestations in 136 patients with chronic HCV infection

\begin{tabular}{lc}
\hline Clinical manifestations & $\boldsymbol{n}(\%)$ \\
\hline Fatigue & $81(59.6)$ \\
Renal involvement & $34(25.0)$ \\
Type 2 diabetes mellitus & $31(22.8)$ \\
Paresthesia & $27(19.9)$ \\
Arthralgia & $25(18.4)$ \\
Purpura & $24(17.6)$ \\
Pulmonary fibrosis & $21(15.4)$ \\
Thyroid dysfunction & $20(14.7)$ \\
Raynaud's phenomenon & $16(11.8)$ \\
B-cell lymphoma & $12(8.8)$ \\
Sicca-syndrome (xerostomia) & $9(6.6)$ \\
Lichen planus & $8(5.9)$ \\
Biological manifestations & \\
Cryoglobulinemia & $51(37.5)$ \\
Thrombocytopenia & $4(31.6)$ \\
ANA & $25(18.4)$ \\
ASMA & $23(16.9)$ \\
ANCA & $18(13.2)$ \\
Anticardiolipin antibodies & $12(8.8)$ \\
Overall & \\
At least 1 extrahepatic manifestation & $104(76.5)$ \\
\hline
\end{tabular}

ANA: Anti-nuclear antibodies; ASMA: Anti-smooth muscle antibodies; ANCA: Anti-neutrophil cytoplasm antibodies.

$3=$ numerous septa without cirrhosis, and $4=$ cirrhosis. Necroinflammatory activity was graded on a scale of A0-A3, where $\mathrm{A} 0=$ no histological activity, $\mathrm{A} 1=$ mild activity, $\mathrm{A} 2$ = moderate activity, and A $3=$ severe activity.

\section{Statistical analysis}

Quantitative data was expressed as mean \pm SD. Univariate analysis used the $\chi^{2}$ - square or Fisher's exact test for comparison of qualitative values. An assessment of the characteristics of HCV infection (demographic, epidemiologic, histologic), associated with the presence of extrahepatic manifestations, was performed using univariate and multivariate logistic regression analysis. Statistical significance was assessed at $P<0.05$. Adjusted odds ratio (OR) and 95\% confidence intervals (CI) were derived from the coefficient of the final multivariate logistic model. The analysis was performed with SPSS v.12.0 statistical software.

\section{RESULTS}

A total of 136 patients with chronic $\mathrm{HCV}$ infection were included in the study, comprising of sixty-two (45.6\%) males and seventy-four $(54.4 \%)$ females. The mean age of the patients was $50.16 \pm 16.08$ years (range $20-80$ years). Fortysix patients $(33.8 \%)$ were $\geqslant 60$ years of age. Thirty-four patients $(25.0 \%)$ had a history of alcohol intake $(\geqslant 50 \mathrm{~g} / \mathrm{d})$. The suspected duration of infection was $\geqslant 20$ years in 70 patients $(51.5 \%)$ and $<20$ years in 66 patients $(48.5 \%)$. Genotyping was performed in sixty patients, fifty-two $(87 \%)$ had genotype 1, $4(6.5 \%)$ genotype 3 , and $4(6.5 \%)$ had mixed genotypes. Metavir scores for inflammatory activity were: A0 in 5 patients (3.7\%), A1 48 (35.3\%), A2 46 (33.8\%), and A3 37 patients (27.2\%). Metavir scores for fibrosis were:
F0 in 12 patients (8.8\%), F1 16 (11.8\%), F2 25 (18.4\%), F3 $27(19.9 \%)$, and F4 in 56 patients $(41.1 \%)$. Twenty patients $(14.7 \%)$ were intravenous drug users. Thirty-seven patients $(27.2 \%)$ were possibly infected during surgical procedures. History of dental manipulation with bleeding was detected in 18 patients $(13.2 \%)$. Needle stick injury was found in 11 health workers $(8.1 \%)$. Fifty of the 136 patients $(36.8 \%)$ had previously been transfused with blood or blood products. Thirty-eight of these 50 patients were women, who received blood transfusions during childbirth, and in 33 of these patients the duration of infection was $\geqslant 20$ years. Nineteen of these 38 women were $\geqslant 60$ years of age at the time of presentation. Twenty of these patients had Metavir stage F4, and $10(10 / 38)$ were Metavir F3.

The overall prevalence of individual extrahepatic manifestations is shown in Table 1. At least one extrahepatic manifestation was identified in 104 patients $(76.5 \%)$. The clinical manifestations, in descending order of prevalence were: fatigue (59.6\%), kidney impairment $(25.0 \%)$, type 2 diabetes mellitus $(22.8 \%)$, paresthesia (19.9\%), arthralgia (18.4\%), palpable purpura predominantly of the lower extremities $(17.6 \%)$, lymphadenopathy $(16.2 \%)$, pulmonary fibrosis $(15.4 \%)$, thyroid dysfunction (14.7\%), Raynaud's phenomenon (11.8\%), B-cell non-Hodgkin's lymphoma (8.8\%), sicca-syndrome $(6.6 \%)$, and lichen planus (5.9\%). All patients with sicca-syndrome had xerostomia, but none had xerophtalmia. Three patients had skin lesions of lichen planus and five had oral lesions. The biological manifestations, in descending order of prevalence were: cryoglobulin (37.5\%), thrombocytopenia (31.6\%), ANA (18.4\%), ASMA (16.9\%), ANCA (13.2\%), anti-cardiolipin antibodies (8.8\%). The ANA, ASMA and ANCA were present in low titers $(\leqslant 1 / 160)$. None of the patients in the study had clearly defined clinical features of autoimmune liver disease.

The relationship between the presence of cryoglobulins and other extrahepatic manifestations is shown in Table 2. Cryoglobulin-positivity was related to the following clinical manifestations: fatigue, purpura, Raynaud's phenomenon, kidney impairment, type 2 diabetes mellitus, arthralgia, paresthesia, pulmonary fibrosis, lymphadenopathy, and B-cell lymphoma. Cryoglobulinpositivity was also associated with the following biological manifestations: thrombocytopenia, and positive ANA, ASMA, ANCA, and anti-cardiolipin autoantibodies. Three female patients ( $\geqslant 60$ years at the time of the study) with advanced liver fibrosis and history of blood transfusions during childbirth, first became cryoglobulin positive and subsequently developed lymphadenooathy over two, three, and five years respectively. Histological analysis of the removed lymph nodes showed low-grade non Hodgkin B-cell lymphoma. The present study did not show any association between the presence of cryoglobulins and thyroid dysfunction, sicca syndrome, and lichen planus (Table 2).

The demographic, epidemiological and liver histological features associated with the extrahepatic manifestations were analyzed by univariate and multivariate logistic regression analysis. The results are shown in Table 3. Using univariate logistic regression analysis there was a positive correlation 
Table 2 Relationship between cryoglobulin-positivity and the presence (\%) of extrahepatic manifestations in patients with chronic HCV infection

\begin{tabular}{|c|c|c|c|c|}
\hline $\begin{array}{l}\text { Extrahepatic } \\
\text { manifestations }\end{array}$ & $\begin{array}{l}\text { Cryoglobulin-positive } \\
\text { patients }(n=51)\end{array}$ & $\begin{array}{l}\text { Cryoglobulin-negative } \\
\text { patients }(n=85)\end{array}$ & $P$ & $\begin{array}{l}\text { Odds ratio } \\
\text { (95\% confidence interval) }\end{array}$ \\
\hline Fatigue & 92.2 & 40.0 & 0.000 & $17.6(5.8-53.4)$ \\
\hline Purpura & 41.2 & 3.5 & 0.000 & $19.1(5.3-68.8)$ \\
\hline Raynaud' phenomenon & 25.5 & 3.5 & 0.000 & $9.3(2.5-34.7)$ \\
\hline Arthralgia & 33.3 & 9.4 & 0.001 & $4.8(1.8-12.2)$ \\
\hline Paresthesia & 41.2 & 7.1 & 0.000 & $9.2(3.3-25.0)$ \\
\hline Renal involvement & 45.1 & 12.4 & 0.000 & $5.5(2.3-12.7)$ \\
\hline Type 2 diabetes & 35.3 & 15.3 & 0.011 & $3.0(1.3-6.8)$ \\
\hline Lymphadenomegaly & 35.3 & 4.7 & 0.000 & $11.0(3.4-35.1)$ \\
\hline Lymphoma & 17.6 & 3.5 & 0.015 & $5.8(1.5-22.7)$ \\
\hline Pulmonary fibrosis & 25.5 & 9.4 & 0.015 & $3.2(1.2-8.6)$ \\
\hline Thyroid dysfunction & 15.7 & 14.1 & & \\
\hline Xerostomia & 11.8 & 3.5 & & \\
\hline Lichen planus & 7.8 & 4.7 & & \\
\hline Thrombocytopenia & 58.8 & 15.3 & 0.000 & $7.9(3.5-17.8)$ \\
\hline ANA & 29.4 & 11.8 & 0.013 & $3.1(1.2-76.0)$ \\
\hline ASMA & 33.3 & 7.1 & 0.000 & $6.5(2.3-18.1)$ \\
\hline ANCA & 25.5 & 5.9 & 0.002 & $5.4(1.9-16.4)$ \\
\hline ACL-antibodies & 17.6 & 3.5 & 0.010 & $5.8(1.5-22.7)$ \\
\hline
\end{tabular}

ANA: Anti-nuclear antibodies; ASMA: Anti-smooth muscle antibodies; ANCA: Anti-neutrophil cytoplasm antibodies; ACL: Anti-cardiolipin.

Table 3 Univariate and multivariate logistic regression analysis of factors associated with the presence of extrahepatic manifestations in patients with chronic HCV infection

\begin{tabular}{|c|c|c|c|c|c|}
\hline Factors & $\begin{array}{l}\text { Patients with the factor }(\%) \text { in } \\
\text { the presence of extrahepatic } \\
\text { manifestations }(n=104)\end{array}$ & $\begin{array}{l}\text { Patients with the factor }(\%) \text { in } \\
\text { the absence of extrahepatic } \\
\text { manifestations }(n=32)\end{array}$ & $\begin{array}{l}\text { Uni-variate } \\
\text { analysis }\end{array}$ & $\begin{array}{l}\text { Multi-variate } \\
\text { analysis }\end{array}$ & $\begin{array}{c}\text { Odds ratio } \\
\text { ( } 95 \% \text { confidence interval) }\end{array}$ \\
\hline Female sex & 59.6 & 37.5 & 0.042 & & \\
\hline Age $\geqslant 60 \mathrm{yr}$ & 43.3 & 3.1 & 0.000 & & \\
\hline Duration of infection $\geqslant 20 \mathrm{yr}$ & 66.3 & 3.1 & 0.000 & 0.001 & $36.3(4.6-284.9)$ \\
\hline $\begin{array}{l}\text { Transfusion of blood and } \\
\text { blood products }\end{array}$ & 43.3 & 15.6 & 0.006 & & \\
\hline Metavir A3 & 30.8 & 15.6 & & & \\
\hline Metavir F4 & 52.9 & 3.1 & 0.000 & 0.011 & $15.4(1.8-125.9)$ \\
\hline Alcohol $\geqslant 50 \mathrm{~g} / \mathrm{d}$ & 24.0 & 28.1 & & & \\
\hline
\end{tabular}

between the presence of extrahepatic manifestations and female sex, older age ( $\geqslant 60$ years), duration of the infection ( $\geqslant 20$ years), transfusion of blood and blood products, and extensive liver fibrosis (Metavir F4). Univariate analysis did not show any correlation between extrahepatic manifestations and the mode of transmission: intravenous drug use $(8.7 \%$ vs $34.4 \%$ for the patients without extrahepatic manifestations), surgical procedures (27.9\% vs $25.5 \%)$, dental manipulation with bleeding $(12.5 \%$ vs $15.6 \%)$, and needle stick injury in health workers $(7.7 \%$ vs $9.4 \%$ ). Univariate logistic regression analysis did not show an association between extrahepatic manifestations and high grade of inflammatory activity in the liver (Metavir A3) and alcohol intake of $\geqslant 50 \mathrm{~g} / \mathrm{d}$ (Table 3). Multivariate logistic regression analysis showed that the most significant association was between extrahepatic manifestations and long duration of infection and advanced liver fibrosis (Table 3).

\section{DISCUSSION}

The present study on 136 patients with chronic HCV infection, showed a high prevalence of extrahepatic clinical and biological manifestations. At least one manifestation was present in $76.5 \%$ of the patients. These results are similar to those reported in a large prospective French study, in which $74 \%$ of 1614 patients with chronic HCV infection had at least one extrahepatic clinical symptom ${ }^{[23]}$. By univariate analysis (Table 3) five risks factors were found to be related with clinical and biological extrahepatic manifestations in our patients: female sex, age $\geqslant 60$ years, transfusion of blood and blood products, duration of the infection $\geqslant 20$ years, and extensive liver fibrosis. By multivariate analysis (Table 3) the most significant risks factors were the longstanding infection and extensive liver fibrosis.

Fatigue was the most frequent non-specific clinical symptom in chronic HCV infection ${ }^{[2]}$. About $60 \%$ patients in this study considered fatigue as the initial or worst symptom of their disease (Table 1). In a prospective study of 1614 individuals with chronic HCV infection, fatigue was present in $53 \%$ of patients ${ }^{[24]}$. It is not known what causes fatigue in chronic HCV infection. The elevated fatigue score ${ }^{[25]}$ is probably related to an increase in serum leptin levels which may interact with serotonin neurotransmission ${ }^{[2]}$. Fatigue can be considered a part of 
the clinical picture of $\mathrm{HCV}$-associated cryoglobulinemia, since this symptom was seen more frequently in cryoglobulin-positive than in cryoglobulin-negative patients (92.2\% vs 40.0\%, OR 17.6, 95\% CI 5.8-53.4).

Hepatitis $\mathrm{C}$ virus escapes immune elimination in chronically infected patients ${ }^{[5]}$. In such patients, CD81mediated activation of $\mathrm{B}$ cells triggers mono-oligoclonal B-lymphocyte expansion and the appearance of various HCV-related autoimmune disorders, including the syndrome of mixed cryoglobulinemia ${ }^{[6,27]}$. A recent meta-analysis showed that $44 \%$ patients with chronic $\mathrm{HCV}$ infection had circulating immune complexes with cryoprecipitating properties ${ }^{[28]}$. In the present study, cryoglobulins were isolated in 51 of the $136(37.5 \%)$ patients, but we were not able to define the type of cryoglobulin in all the cases. However, there was considerable evidence to suggest that $\mathrm{HCV}$ was associated with type II mixed cryoglobulinemia, with clinical features of vasculitis which mainly affects the small sized blood vessels of the skin, joints, nerves, and kidneys ${ }^{[5,29]}$. Skin is the most frequently involved target organ ${ }^{[30]}$. In previous studies, palpable purpura was observed in $10 \%$ to $21 \%$ patients with clinically manifested cryoglobulinemic syndrome ${ }^{[11]}$, and in $7 \%$ of all HCV infected patients ${ }^{[8]}$. We observed palpable purpura, predominantly over the lower extremities, in 24 of the 136 patients (17.6\%), with much higher prevalence in cryoglobulin-positive than in cryoglobulin-negative patients $(41.2 \%$ vs $3.5 \%$, OR 19.1, 95\% CI 5.3-68.8). Symptoms related to Raynaud' $\mathrm{s}$ phenomenon were observed in 16 of the 136 patients $(11.8 \%)$, with higher prevalence in cryoglobulin-positive than in cryoglobulin-negative patients $(25.5 \%$ vs $3.5 \%$, OR 9.3, 95\% CI 2.5-34.7). Pruritus, Raynaud's phenomenon, and palpable purpura of the lower extremities are the main skin manifestations of chronic HCV infection, which is consistent with the findings of previous studies $^{[11,31,32]}$. However, considering the high frequency of cryoglobulins in HCV patients, severe symptomatic mixed cryoglobulinemia with the clinical presentation of diffuse vasculitis was rare, seen in only $1 \%$ of cryoglobulinpositive patients ${ }^{[23]}$. Polyarteritis nodosa-type of clinical presentation was not observed in the present study.

Previous studies have shown that arthralgia is present in $44.7 \%$ patients with $\mathrm{HCV}$-associated mixed cryoglobulinemia ${ }^{33]}$ and in $19 \%$ of all HCV infected patients ${ }^{[8]}$. The clinical picture may mimic rheumatoid arthritis, especially since rheumatoid factor was present in $71 \%$ of cases $^{[34]}$, but there was no joint destruction, and antibodies to cyclic citrullinated peptides, which are highly specific for rheumatoid arthritis, were absent ${ }^{[35]}$. In the present study, arthralgia was present in $18.4 \%$ patients, with higher prevalence in cryoglobulin-positive than in cryoglobulin-negative patients $(33.3 \%$ vs $9.9 \%$, OR 4.8, $95 \%$ CI 1.8-12.2). None of the patients in the present study met the diagnostic criteria for rheumatoid arthritis.

Peripheral nervous system involvement is a characteristic feature of the more severe forms of clinically apparent $\mathrm{HCV}$-cryoglobulinemia ${ }^{[3]}$. Peripheral neuropathy, manifested by paresthesia, was noted in $17 \%$ of all HCV patients ${ }^{[23]}$ and in $37 \%$ to $80 \%$ of the patients with $\mathrm{HCV}$-associated mixed cryoglobulinemia ${ }^{[36,37]}$. We observed paresthesia in 19.9\% of all HCV infected patients, with a higher prevalence in cryoglobulinpositive than in cryoglobulin-negative patients $(41.2 \%$ vs 7.1\%, OR 9.2, 95\% CI 3.3-25.0). Sensory nerves are mainly affected in patients with $\mathrm{HCV}$-associated mixed cryoglobulinemia ${ }^{[38]}$. Neuropathological data shows axonal degeneration, differential fascicular loss of axons, signs of demyelinization, and small-vessel vasculitis with mononuclear cell infiltrates in the perivascular areas ${ }^{[38,39]}$.

Chronic HCV infection can trigger the immune complex syndrome of cryoglobulin deposition and type-1 membranoproliferative glomerulonephritis ${ }^{[40]}$. Diffuse membranoproliferative glomerulonephritis is found in $83 \%$ of cryoglobulinemic renal disease ${ }^{[41]}$. Misiani et a ${ }^{{ }^{42]}}$ found a high prevalence of HCV antibodies (66\%) and HCV RNA $(81 \%)$ in the serum of patients with cryoglobulinemic glomerulonephritis. Only $2 \%$ of the controls (patients with noncryoglobulinemic glomerulopathies) had HCV antibodies ${ }^{[42]}$. In Japan, the virus was found in $60 \%$ patients with membranoproliferative glomerulonephritis ${ }^{[43]}$. Clinically obvious renal disease was present in $20 \%$ to $30 \%$ of cryoglobulin-positive patients with $\mathrm{HCV}$ infection ${ }^{[7,23,44]}$. In $55 \%$ of these patients, the findings include mild proteinuria, mild microscopic hematuria and mild renal insuffiency ${ }^{[45,46]}$. Arterial hypertension is present in $80 \%$ patients $^{[45,47]}$. In the present study, 34 of the $136 \mathrm{HCV}$ patents $(25 \%)$ had mild proteinuria, hypertension and serum creatinine levels above the upper limit of normal. These symptoms are related to HCV-cryoglobulinemia, since their prevalence was higher in cryoglobulin-positive than in cryoglobulin-negative patients $(45.1 \%$ vs $12.4 \%$, OR 5.5, 95\% CI 2.3-12.7). Renal abnormalities during the course of $\mathrm{HCV}$ infection are usually diagnosed in most patients between the fifth and sixth decades of life, and occur slightly more frequently in women than men ${ }^{[45,48]}$. Risk factors for the development of severe renal failure at follow-up of these patients include age, serum creatinine level, and proteinuria at the onset of renal disease ${ }^{[41]}$. Cryoglobulin-related nephropathy has been reported to progress to chronic renal failure requiring dialysis in $10 \%$ patients ${ }^{[4]}$, but the overall survival at 10 years was $80 \%{ }^{[41]}$.

Case-control studies show an increase in the prevalence of type 2 diabetes mellitus $(14.5 \%$ to $24 \%)$ in patients with chronic HCV infection ${ }^{[13,49,50]}$. These findings have been confirmed in a representative sample of the general population in the $\mathrm{USA}^{[51]}$. Reports from diverse geographic regions have shown a 2 - to 10 - fold increase in the prevalence of diabetes in patients with $\mathrm{HCV}$ infection compared to liver disease controls ${ }^{[51-53]}$. The highest prevalence (up to $50 \%$ ) was noted in patients with $\mathrm{HCV}$-associated liver cirrhosis ${ }^{[54-56]}$. Our findings are consistent with these studies. We found type 2 diabetes in 31 of the $136 \mathrm{HCV}$ patients $(22.8 \%)$, which is higher than the prevalence $(8.0 \%)$ in the general population of our country. Antonelli et al ${ }^{[57]}$ found a higher prevalence $(14.4 \%)$ of type 2 diabetes in HCV patients with mixed cryoglobulinemia compared to HCV-negative age-matched controls $(6.9 \%)$ and the general population in northern Italy $(2.5 \%-3.3 \%)$. We also found a higher prevalence of type 2 diabetes in cryoglobulin-positive than in cryoglobulin-negative patients $(35.3 \%$ vs $15.3 \%$, OR 3.0, 
95\% CI 1.3-6.8). Given the biology of HCV, which is both hepatotropic and lymphotropic, an immune-mediated mechanism may explain the raised prevalence of type 2 diabetes in HCV-patients with mixed cryoglobulinemia ${ }^{[57]}$. Recent studies suggest that insulin resistance mediated by proinflammatory cytokines, rather than a deficit in insulin secretion, is the primary pathogenic mechanism involved in the development of type 2 diabetes in HCV infection ${ }^{[58]}$.

Soresi et al ${ }^{[59]}$ detected abdominal lymphadenopathy in $22 \%$ patients with $\mathrm{HCV}$ infection and persistently normal transaminases, and in $38 \%$ of those with high alanine aminotransferase values. Multiple logistic regression analysis showed a significant relationship between abdominal lymphadenopathy and histological abnormalities of the liver, presence of HCV RNA in the serum and gamma-globulin levels ${ }^{[59]}$. Lymphadenopathy in chronic HCV infection indicates a possible interaction between viral antigens and the immune system ${ }^{[60]}$. This interaction may be complicated by autoimmunity, cryoglobulinemia and B cell malignancy ${ }^{\left[{ }^{[0]}\right.}$. In the present study, lymphadenopathy was seen in 22 of the $136 \mathrm{HCV}$ patients $(16.2 \%)$, with a higher prevalence in cryoglobulinpositive than in cryoglobulin-negative patients $(35.3 \%$ vs 4.7\%, OR 11.0, 95\% CI 3.4-35.1). Epidemiological studies have confirmed a link between HCV infection and B-cell non Hodgkin's lymphoma ${ }^{[61-63]}$. In a recent meta-analysis, the prevalence of $\mathrm{HCV}$ infection in patients with B-cell non Hodgkin's lymphoma was approximately 15\%, which is much higher than the prevalence of $\mathrm{HCV}$ in the general population ${ }^{[64]}$. Clonal B cell proliferation was observed in patients with a longer duration of HCV infection, type II cryoglobulin, and vasculitis ${ }^{[5,65,66]}$. Over $90 \%$ patients who developed non-Hodgkin lymphoma had type II cryoglobulins $^{[64]}$. About $10 \%$ patients with HCV mixed cryoglobulinemia evolved into lymphoma ${ }^{[6]}$. In a series of 231 Italian patients with mixed cryoglobulinemia, 20 developed B-cell lymphoma after a mean of 8.8 years ${ }^{[7]}$. The overall risk of non-Hodgkin lymphoma in patients with cryoglobulinemic syndrome was 35 times higher than that in the general population ${ }^{[64]}$. Our findings are in agreement with the results reported from Italy ${ }^{[67]}$. In the present study, B-cell non Hodgkin's lymphoma was diagnosed in 12 of the $136 \mathrm{HCV}$ patients $(8.8 \%)$ with higher prevalence in cryoglobulin-positive than in cryoglobulin-negative patients $(17.6 \%$ vs $3.5 \%$, OR 5.8, 95\% CI 1.5-22.7). The exact prevalence of $\mathrm{HCV}$ associated lymphoma in our country may be much higher, since patients with abdominal and/or mediastinal lymphadenopathy (without enlargement of peripheral lymph nodes) did not provide consent for invasive diagnostic surgical procedures. The appearance of cryoglobulins, peripheral lymphadenopathy and low-grade B-cell lymphoma in 3 women during follow-up suggested that benign lymphoproliferation, triggered by the virus, can evolve into malignant B cell lymphoma. It is possible that genetic and environmental factors ${ }^{[68]}$ play a role in the higher prevalence of HCV-associated lymphoma in SouthEast Europe, including our country, compared to Northern Europe $^{[69]}$. Based on the available evidence it appears that $\mathrm{HCV}$ is an important risk factor for B-cell malignancy in areas with a high prevalence of $\mathrm{HCV}$ infection ${ }^{[5]}$, which in our country is $1.3 \%$.

Ueda et al ${ }^{[70]}$ noted a higher prevalence of anti-HCV antibodies in Japanese patients with idiopathic pulmonary fibrosis compared to the general population. The prevalence of idiopathic pulmonary fibrosis in anti-HCV positive patients was $9.4 \%{ }^{[71]}$. HCV patients with mixed cryoglobulinemia have been found to have asymptomatic interstitial lung fibrosis diagnosed by chest X-ray and highresolution computed tomography ${ }^{[15]}$. Pulmonary fibrosis in HCV-related cryoglobulinemia is perhaps triggered by local deposition of circulating HCV-containing immune complexes ${ }^{[72]}$. In the present study 21 of the 136 HCV patients $(15.4 \%)$ showed pulmonary fibrosis on routine X-ray examination; the frequency of pulmonary fibrosis was higher in cryoglobulin-positive than in the cryoglobulin-negative patients $(25.5 \%$ vs $9.4 \%$, OR 3.2 , $95 \%$ CI 1.2-8.6). These findings need further confirmation with the use of more sophisticated radiological techniques.

Serum autoantibodies are commonly seen in patients with chronic HCV infection. In a study by Lenzi et al ${ }^{[9]}$ the overall prevalence of non-organ specific autoantibodies was significantly higher in anti-HCV positive patients compared to healthy subjects, and $\mathrm{HBsAg}$ positive controls $(25 \%$ vs $6 \%$ and $7 \%$ respectively). Several studies have evaluated the prevalence of ANA and ASMA, with figures ranging from $4.4 \%$ to $41 \%{ }^{[8,10,34]}$ and $7 \%$ to $66 \%$ respectively ${ }^{[23,34,73]}$. In the present study, positive ANA and ASMA tests were seen in $18.4 \%$ and $16.9 \%$ patients respectively. The anti-ANA and ASMA antibodies were found in low titers $(\leqslant 1 / 160)$, and were detected predominantly in the cryoglobulin-positive patients (Table 2). However, none of the patients had a clearly defined clinical picture of autoimmune liver disease. Recent data suggests that the HCV core particles concentrated in the cryoprecipitate play a role in the interaction between the cryoglobulins, endothelial cells and neutrophil granulocytes ${ }^{[74]}$. The main antigens in $\mathrm{HCV}$ patients with a positive ANCA test are proteinase 3 and dihydrolipoamine dehydrogenase ${ }^{[75]}$. A positive ANCA has been found in $10 \%$ patients with $\mathrm{HCV}$-associated mixed cryoglobulinemia ${ }^{[76]}$. In the present study, ANCA was present in 18 of the 136 patients $(13.2 \%)$, with higher prevalence in cryoglobulin-positive than cryoglobulinnegative patients (25.5\% vs 5.9\%, OR 5.4, 95\% CI 1.9-16.4). $\mathrm{HCV}$ patients with ANCA had a higher prevalence of skin involvement, anemia, abnormal liver function tests and elevated alpha feto-protein levels ${ }^{[75]}$. Anticardiolipin antibodies have been observed in $3.3 \%$ to $22 \%$ of $\mathrm{HCV}$ patients ${ }^{[77-79]}$. These antibodies were found more frequently in patients with $\mathrm{HCV}$-associated cryoglobulinemia ${ }^{[80]}$. Our findings are consistent with previously reported data. In the present study, 12 of the 136 patients $(8.8 \%)$ had anticardiolipin antibodies, with higher prevalence in cryoglobulin-positive than in cryoglobulin-negative patients (17.6\% vs 3.5\%, OR 5.8, 95\% CI 1.5-22.7). According to a recent study, these antibodies do not have any clinical significance in $\mathrm{HCV}$ patients, since they are anti- $\beta 2$-glicoprotein I independent ${ }^{[78]}$. The auto-antibodies seen in patients with HCV infection appear to resemble those seen in chronic viral infections - the autoantibody titers are low, frequently found during the clinical course 
of cryoglobulinemia, but do not produce a typical autoimmune disease ${ }^{[29,80]}$.

The prevalence of thrombocytopenia is higher in patients with chronic HCV infection than in the general population $^{[14]}$. In a series of 368 patients with chronic HCV infection, Nagamine et al ${ }^{[81]}$ detected 151 cases (41\%) of thrombocytopenia. Our findings also suggest a high prevalence of thrombocytopenia in patients with chronic HCV infection $(31.6 \%)$. This can be explained by the large number of patients with cirrhosis in the present study. Platelet sequestration and destruction in the spleen ${ }^{[82,83]}$, along with low thrombopoetin production ${ }^{[83,84]}$ play an important role in the pathogenesis of thrombocytopenia. However, a direct viral infection of the megakariocytes ${ }^{[85]}$ and autoimmune mechanisms ${ }^{[86,87]}$ cannot be ruled out. The higher prevalence of thrombocytopenia in cryoglobulinpositive than in cryoglobulin-negative patients $(58.8 \% \mathrm{vs}$ $15.3 \%$, OR $7.9,95 \%$ CI 3.5-17.8) in the present study may reflect the role of immune dysregulation in causing both abnormalities.

In previous studies, thyroid specific antibodies were observed in $22.1 \%$ patients with chronic HCV infection, but the presence of thyroid dysfunction was not different compared to age and gender matched controls ${ }^{[18]}$. Thyroid dysfunction was seen in $14.7 \%$ of our 136 untreated $\mathrm{HCV}$ patients, and there was no association with the presence of cryoglobulins. However, up to $12.6 \% \mathrm{HCV}$ patients developed thyroid dysfunction during or after IFN therapy ${ }^{[88-90]}$, with a significant association with female gender ${ }^{[19]}$.

Lymphocytic infiltration of the salivary glands has been described in $57 \%$ patients with chronic HCV infection compared to $5 \%$ in deceased controls ${ }^{[16]}$. A direct role of the virus is suggested by studies on mice expressing HCV envelope proteins E1 and E2 in the liver and salivary glands ${ }^{[91]}$. Sialadenitis developed in $84 \% \mathrm{HCV}$ infected mice compared to $2 \%$ in control littermates and $0 \%$ in $\mathrm{HCV}$ core transgenic animals ${ }^{[91]}$. Up to $10 \%$ patients with chronic HCV infection may develop symptoms of xerostomia and xerophthalmia ${ }^{[8]}$, whereas less than $5 \%$ of patients with confirmed Sjogren syndrome are carriers of $\mathrm{HCV}^{[17]}$. In the present study, xerostomia was seen in $6.6 \%$ patients, but none had xerophthalmia. Our results show a much higher prevalence of xerostomia in cryoglobulin-positive patients, however there was no difference compared to those without cryoglobulins (Table 2). In a French study, the classic Sjogren syndrome (xerostomia, xerophthalmia, histological stages III and IV in the Chilshom scale, and anti-SSA or antiSSB antibodies) was observed only in $1 \%$ of patients with chronic HCV infection ${ }^{[32]}$.

Clinical studies, predominantly from the Mediterranean area and Japan, suggest that lichen planus, mainly the oral form, is associated with HCV infection ${ }^{[22-94]}$. The overall prevalence of anti-HCV antibodies in Spanish patients with lichen planus was $29.2 \%{ }^{[12]}$. Nagao et a ${ }^{[92]}$ found serum anti-HCV antibodies in $28(62 \%)$ and serum HCV RNA in $27(60 \%)$ of 45 Japanese patients with oral lichen planus. However, these results have not been confirmed by reports from other regions ${ }^{[32,95]}$. The geographical differences could be related to immunogenetic factors since the allele HLA-DR6 is expressed in a significant proportion of Italian patients with oral lichen planus and $\mathrm{HCV}$ infection ${ }^{[94]}$. The frequency of lichen planus in our HCV patients $(5.9 \%)$ is similar to that reported by Pawlotsky et $a^{[32]}$ in France (5\%). We found oral lesions of lichen planus in 5 patients and skin lesions in 3 patients. In the present study, we did not find any association between cryoglobulinemia and the presence of lichen planus (Table 2). Pilli et $a^{[96]}$ detected HCV-specific T cells with phenotypic and functional characteristics of terminally differentiated effector cells at the site of the oral lesions. These findings and the detection of HCV RNA strands in the lichen tissue ${ }^{[97]}$ suggests a possible role for HCVspecific $\mathrm{T}$-cell responses in the pathogenesis of lichen planus associated with HCV infection ${ }^{[98]}$.

Our study has demonstrated a high prevalence of extrahepatic manifestations in Bulgarian patients with chronic HCV infection. Most of these manifestations are the consequence of impaired lymphoproliferation and show an association with cryoglobulin production. Clinical features such as fatigue, palpable purpura, Raynaud's phenomenon, arthralgia, paresthesia, kidney impairment, type 2 diabetes, pulmonary fibrosis, lymphadenopathy, B cell lymphoma, thrombocytopenia and non-organ specific autoantibodies can be regarded as a part of the clinical spectrum of $\mathrm{HCV}$-associated cryoglobulinemia. On the other hand, thyroid dysfunction, sicca-syndrome and lichen planus are also seen in patients with chronic $\mathrm{HCV}$ infection, but were not associated with the presence of cryoglobulins in the present study. Extrahepatic manifestations were observed more frequently in older women with longstanding infection, advanced liver fibrosis and HCV infection acquired through transfusion of blood and blood products during childbirth. These findings suggest that the dose of the virus and the route of transmission may be important factors associated with extrahepatic manifestations. The long duration of $\mathrm{HCV}$ infection and extensive liver fibrosis were the most frequent findings associated with extrahepatic manifestations, but the pathogenesis of such an association is unclear ${ }^{[1,23]}$. Progression of liver fibrosis and the development of systemic-portal venous anastomosis allows the passage of antigens directly into the systemic circulation, thus bypassing the liver filter and resulting in chronic interaction with the immune system ${ }^{[23]}$. Some of the immunological defects are the consequence of HCV interaction with dendritic cells and a shift from Th1 to Th2 cytokine profile ${ }^{[99,100]}$.

Patients with chronic HCV infection have a high prevalence of extrahepatic manifestations. These manifestations are found more frequently in the patients with a long duration of infection and liver cirrhosis, even in the absence of a clearly defined clinical picture of hepatic illness. Most of these manifestations are associated with impaired lymphoproliferation and cryoglobulin production, triggered by hepatitis $\mathrm{C}$ virus. The benign lymphoproliferation, associated with cryoglobulinemia, can evolve into malignant B cell lymphoma. Physicians should be aware of the extrahepatic signs and symptoms of $\mathrm{HCV}$ infection. HCV should be tested in all patients with these manifestations. This may lead to early diagnosis and successful treatment of chronic HCV infection. 


\section{COMMENTS}

\section{Background}

Hepatitis C virus (HCV) affects not only the liver, but other tissues, organs, and systems as well. In our practice, several patients with chronic HCV infection present with extrahepatic manifestations, even in the absence of a clearly defined clinical picture of hepatic illness. Lymphoproliferative disorders, triggered by the virus, are frequently seen in South-Eastern Europe, where Bulgaria is located.

\section{Research frontiers}

The aim of the present study was to assess the prevalence of different extrahepatic manifestations in Bulgarian patients with chronic HCV infection, to identify extrahepatic manifestations associated with impaired lymphoproliferation and cryoglobulin production, and to determine which patients are at greater risk of developing extrahepatic manifestations of chronic HCV infection.

\section{Innovations and breakthroughs}

We observed a high prevalence of extrahepatic manifestations $(76.5 \%)$ in patients with chronic HCV infection. Patients with longstanding infection and cirrhosis had a higher risk of developing such manifestations. In the present study, most of the extrahepatic manifestations were associated with impaired lymphoproliferation and cryoglobulin production, with the exception of sicca syndrome, thyroid dysfunction and lichen planus. The presence of B-cell non Hodgkin's lymphoma was observed in $8.8 \%$ patients, with a higher prevalence in cryoglobulin-positive compared with cryoglobulin-negative patients (17.6\% vs 3.5\%, OR 5.8, 95\% Cl 1.5-22.7).

\section{Applications}

Physicians should be aware of the extrahepatic signs and symptoms of HCV infection. HCV should be tested in patients who have any of these manifestations. This may lead to early diagnosis and successful treatment of chronic HCV infection. The treatment of lymphoproliferative disorders, including B-cell non Hodgkin's lymphoma poses a challenge, and requires new therapeutic strategies.

\section{Terminology}

Hepatitis $\mathrm{C}$ virus (HCV) escapes immune elimination. $\mathrm{HCV}$ interacts with hepatocytes and $B$ lymphocytes through a common (CD81) receptor. CD81mediated activation of $B$ cells in chronically infected patients can trigger clonal B-lymphocyte proliferation with cryoglobulin' production, and evolution of disease into B-cell non Hodgkin's lymphoma. HCV can interact, with or without immune mediated mechanisms, with different tissues, organs, and systems.

\section{Peer review}

The authors assessed the prevalence of extrahepatic manifestations in Bulgarian patients with chronic HCV infection and identified the clinical and biological manifestations associated with cryoglobulinemia.

\section{REFERENCES}

$1 \quad$ Hadziyannis SJ. The spectrum of extrahepatic manifestations in hepatitis C virus infection. J Viral Hepat 1997; 4: 9-28

2 Sène D, Saadoun D, Limal N, Piette JC, Cacoub P. [Update in Hepatitis $\mathrm{C}$ virus associated extrahepatic manifestations]. Rev Med Interne 2007; 28: 388-393

3 Zignego AL, Ferri C, Pileri SA, Caini P, Bianchi FB. Extrahepatic manifestations of Hepatitis C Virus infection: a general overview and guidelines for a clinical approach. Dig Liver Dis 2007; 39: 2-17

4 Pascual M, Perrin L, Giostra E, Schifferli JA. Hepatitis C virus in patients with cryoglobulinemia type II. J Infect Dis 1990; 162: 569-570

5 Zignego AL, Giannini C, Ferri C. Hepatitis C virus-related lymphoproliferative disorders: an overview. World J Gastroenterol 2007; 13: 2467-2478

6 Ghinoi A, Mascia MT, Puccini R, Ferri C. [Autoimmune and lymphoproliferative HCV-correlated manifestations: example of mixed cryoglobulinaemia (review)]. G Ital Nefrol 2004; 21: 225-237

7 Ferri C, Sebastiani M, Giuggioli D, Cazzato M, Longombardo G, Antonelli A, Puccini R, Michelassi C, Zignego AL. Mixed cryoglobulinemia: demographic, clinical, and serologic features and survival in 231 patients. Semin Arthritis Rheum 2004; 33: 355-374

8 Cacoub P, Renou C, Rosenthal E, Cohen P, Loury I, LoustaudRatti V, Yamamoto AM, Camproux AC, Hausfater P, Musset L, Veyssier P, Raguin G, Piette JC. Extrahepatic manifestations associated with hepatitis $C$ virus infection. A prospective multicenter study of 321 patients. The GERMIVIC. Groupe d'Etude et de Recherche en Medecine Interne et Maladies Infectieuses sur le Virus de l'Hepatite C. Medicine (Baltimore) 2000; 79: 47-56

9 Lenzi M, Bellentani S, Saccoccio G, Muratori P, Masutti F, Muratori L, Cassani F, Bianchi FB, Tiribelli C. Prevalence of non-organ-specific autoantibodies and chronic liver disease in the general population: a nested case-control study of the Dionysos cohort. Gut 1999; 45: 435-441

10 Yee LJ, Kelleher P, Goldin RD, Marshall S, Thomas HC, Alberti A, Chiaramonte M, Braconier JH, Hall AJ, Thursz MR Antinuclear antibodies (ANA) in chronic hepatitis $C$ virus infection: correlates of positivity and clinical relevance. J Viral Hepat 2004; 11: 459-464

11 Poljacki M, Gajinov Z, Ivkov M, Matić M, Golusin Z. [Skin diseases and hepatitis virus C infection]. Med Pregl 2000; 53: 141-145

12 del Olmo JA, Pascual I, Bagán JV, Serra MA, Escudero A, Rodriguez F, Rodrigo JM. Prevalence of hepatitis $C$ virus in patients with lichen planus of the oral cavity and chronic liver disease. Eur J Oral Sci 2000; 108: 378-382

13 Zein CO, Levy C, Basu A, Zein NN. Chronic hepatitis C and type II diabetes mellitus: a prospective cross-sectional study. Am J Gastroenterol 2005; 100: 48-55

14 Wang CS, Yao WJ, Wang ST, Chang TT, Chou P. Strong association of hepatitis $\mathrm{C}$ virus (HCV) infection and thrombocytopenia: implications from a survey of a community with hyperendemic HCV infection. Clin Infect Dis 2004; 39 790-796

15 Manganelli P, Salaffi F, Pesci A. [Hepatitis C virus and pulmonary fibrosis]. Recenti Prog Med 2002; 93: 322-326

16 Haddad J, Deny P, Munz-Gotheil C, Ambrosini JC, Trinchet JC, Pateron D, Mal F, Callard P, Beaugrand M. Lymphocytic sialadenitis of Sjögren's syndrome associated with chronic hepatitis C virus liver disease. Lancet 1992; 339: 321-323

17 Ramos-Casals M, Loustaud-Ratti V, De Vita S, Zeher M, Bosch JA, Toussirot E, Medina F, Rosas J, Anaya JM, Font J. Sjögren syndrome associated with hepatitis $C$ virus: a multicenter analysis of 137 cases. Medicine (Baltimore) 2005; 84: 81-89

18 Huang MJ, Tsai SL, Huang BY, Sheen IS, Yeh CT, Liaw YF. Prevalence and significance of thyroid autoantibodies in patients with chronic hepatitis $C$ virus infection: a prospective controlled study. Clin Endocrinol (Oxf) 1999; 50: 503-509

19 Kabbaj N, Guedira MM, El Atmani H, El Alaoui M Mohammadi M, Benabed K, Lachkar H, Benaïssa A. Thyroid disorders during interferon alpha therapy in 625 patients with chronic hepatitis C: a prospective cohort study. Ann Endocrinol (Paris) 2006; 67: 343-347

20 Germer JJ, Rys PN, Thorvilson JN, Persing DH. Determination of hepatitis $\mathrm{C}$ virus genotype by direct sequence analysis of products generated with the Amplicor HCV test. J Clin Microbiol 1999; 37: 2625-2630

21 Winfield JB, Koffler D, Kunkel HG. Specific concentration of polynucleotide immune complexes in the cryoprecipitates of patients with systemic lupus erythematosus. J Clin Invest 1975 56: $563-570$

22 Intraobserver and interobserver variations in liver biopsy interpretation in patients with chronic hepatitis C. The French METAVIR Cooperative Study Group. Hepatology 1994; 20: $15-20$

23 Cacoub P, Poynard T, Ghillani P, Charlotte F, Olivi M, Piette JC, Opolon P. Extrahepatic manifestations of chronic hepatitis C. MULTIVIRC Group. Multidepartment Virus C. Arthritis Rheum 1999; 42: 2204-2212

24 Poynard T, Cacoub P, Ratziu V, Myers RP, Dezailles MH, Mercadier A, Ghillani P, Charlotte F, Piette JC, Moussalli J. Fatigue in patients with chronic hepatitis C. J Viral Hepat 2002; 


\section{9: 295-303}

25 Fisk JD, Pontefract A, Ritvo PG, Archibald CJ, Murray TJ. The impact of fatigue on patients with multiple sclerosis. Can J Neurol Sci 1994; 21: 9-14

26 Piche T, Vanbiervliet G, Cherikh F, Antoun Z, Huet PM, Gelsi E, Demarquay JF, Caroli-Bosc FX, Benzaken S, Rigault MC, Renou C, Rampal P, Tran A. Effect of ondansetron, a 5-HT3 receptor antagonist, on fatigue in chronic hepatitis C: a randomised, double blind, placebo controlled study. Gut 2005; 54: 1169-1173

27 Rosa D, Saletti G, De Gregorio E, Zorat F, Comar C, D'Oro U, Nuti S, Houghton M, Barnaba V, Pozzato G, Abrignani S. Activation of naïve B lymphocytes via CD81, a pathogenetic mechanism for hepatitis C virus-associated B lymphocyte disorders. Proc Natl Acad Sci USA 2005; 102: 18544-18549

28 Kayali Z, Buckwold VE, Zimmerman B, Schmidt WN. Hepatitis C, cryoglobulinemia, and cirrhosis: a meta-analysis. Hepatology 2002; 36: 978-985

29 Agnello V, De Rosa FG. Extrahepatic disease manifestations of HCV infection: some current issues. J Hepatol 2004; 40: 341-352

30 Sansonno D, Carbone A, De Re V, Dammacco F. Hepatitis C virus infection, cryoglobulinaemia, and beyond. Rheumatology (Oxford) 2007; 46: 572-578

31 Chia SC, Bergasa NV, Kleiner DE, Goodman Z, Hoofnagle JH, Di Bisceglie AM. Pruritus as a presenting symptom of chronic hepatitis C. Dig Dis Sci 1998; 43: 2177-2183

32 Pawlotsky JM, Ben Yahia M, Andre C, Voisin MC, Intrator L, Roudot-Thoraval F, Deforges L, Duvoux C, Zafrani ES, Duval J. Immunological disorders in $\mathrm{C}$ virus chronic active hepatitis: a prospective case-control study. Hepatology 1994; 19: 841-848

33 Leone N, Pellicano R, Ariata Maiocco I, Modena V, Marietti G, Rizzetto M, Ponzetto A. Mixed cryoglobulinaemia and chronic hepatitis $\mathrm{C}$ virus infection: the rheumatic manifestations. J Med Virol 2002; 66: 200-203

34 Pawlotsky JM, Roudot-Thoraval F, Simmonds P, Mellor J, Ben Yahia MB, André C, Voisin MC, Intrator L, Zafrani ES, Duval J, Dhumeaux D. Extrahepatic immunologic manifestations in chronic hepatitis $\mathrm{C}$ and hepatitis $\mathrm{C}$ virus serotypes. Ann Intern Med 1995; 122: 169-173

35 Lormeau C, Falgarone G, Roulot D, Boissier MC. Rheumatologic manifestations of chronic hepatitis $C$ infection. Joint Bone Spine 2006; 73: 633-638

36 Zaltron S, Puoti M, Liberini P, Antonini L, Quinzanini M, Manni M, Forleo MA, Rossi S, Spinetti A, Zanini B, Carosi G. High prevalence of peripheral neuropathy in hepatitis $C$ virus infected patients with symptomatic and asymptomatic cryoglobulinaemia. Ital J Gastroenterol Hepatol 1998; 30: 391-395

37 Migliaresi S, Di Iorio G, Ammendola A, Ambrosone L, Sanges G, Ugolini G, Sampaolo S, Bravaccio F, Tirri G. [Peripheral nervous system involvement in HCV-related mixed cryoglobulinemia] Reumatismo 2001; 53: 26-32

38 Cacoub P, Saadoun D, Limal N, Léger JM, Maisonobe T. Hepatitis $C$ virus infection and mixed cryoglobulinaemia vasculitis: a review of neurological complications. AIDS 2005; 19 Suppl 3: S128-S134

39 Authier FJ, Bassez G, Payan C, Guillevin L, Pawlotsky JM, Degos JD, Gherardi RK, Belec L. Detection of genomic viral RNA in nerve and muscle of patients with HCV neuropathy. Neurology 2003; 60: 808-812

40 Meyers CM, Seeff LB, Stehman-Breen CO, Hoofnagle JH. Hepatitis $C$ and renal disease: an update. Am J Kidney Dis 2003; 42: 631-657

41 Roccatello D, Fornasieri A, Giachino O, Rossi D, Beltrame A, Banfi G, Confalonieri R, Tarantino A, Pasquali S, Amoroso A, Savoldi S, Colombo V, Manno C, Ponzetto A, Moriconi L, Pani A, Rustichelli R, Di Belgiojoso GB, Comotti C, Quarenghi MI. Multicenter study on hepatitis $C$ virus-related cryoglobulinemic glomerulonephritis. Am J Kidney Dis 2007; 49: $69-82$

42 Misiani R, Bellavita P, Fenili D, Borelli G, Marchesi D, Massazza M, Vendramin G, Comotti B, Tanzi E, Scudeller G. Hepatitis $C$ virus infection in patients with essential mixed cryoglobulinemia. Ann Intern Med 1992; 117: 573-577
43 Yamabe H, Johnson RJ, Gretch DR, Fukushi K, Osawa $\mathrm{H}$, Miyata $\mathrm{M}$, Inuma $\mathrm{H}$, Sasaki T, Kaizuka M, Tamura N. Hepatitis $C$ virus infection and membranoproliferative glomerulonephritis in Japan. J Am Soc Nephrol 1995; 6: 220-223

44 Daghestani L, Pomeroy C. Renal manifestations of hepatitis C infection. Am J Med 1999; 106: 347-354

45 D'Amico G. Renal involvement in hepatitis $C$ infection: cryoglobulinemic glomerulonephritis. Kidney Int 1998; 54 650-671

46 Beddhu S, Bastacky S, Johnson JP. The clinical and morphologic spectrum of renal cryoglobulinemia. Medicine (Baltimore) 2002; 81: 398-409

47 Tarantino A, Campise M, Banfi G, Confalonieri R, Bucci A, Montoli A, Colasanti G, Damilano I, D’Amico G, Minetti L. Long-term predictors of survival in essential mixed cryoglobulinemic glomerulonephritis. Kidney Int 1995; 47: 618-623

48 Tsui JI, Vittinghoff E, Shlipak MG, O'Hare AM. Relationship between hepatitis $\mathrm{C}$ and chronic kidney disease: results from the Third National Health and Nutrition Examination Survey. J Am Soc Nephrol 2006; 17: 1168-1174

49 Grimbert S, Valensi P, Lévy-Marchal C, Perret G, Richardet JP, Raffoux C, Trinchet JC, Beaugrand M. High prevalence of diabetes mellitus in patients with chronic hepatitis C. A casecontrol study. Gastroenterol Clin Biol 1996; 20: 544-548

50 Mason AL, Lau JY, Hoang N, Qian K, Alexander GJ, Xu L, Guo L, Jacob S, Regenstein FG, Zimmerman R, Everhart JE, Wasserfall C, Maclaren NK, Perrillo RP. Association of diabetes mellitus and chronic hepatitis $\mathrm{C}$ virus infection. Hepatology 1999; 29: 328-333

51 Mehta SH, Brancati FL, Strathdee SA, Pankow JS, Netski D, Coresh J, Szklo M, Thomas DL. Hepatitis $C$ virus infection and incident type 2 diabetes. Hepatology 2003; 38: 50-56

52 Ozyilkan E, Arslan M. Increased prevalence of diabetes mellitus in patients with chronic hepatitis $\mathrm{C}$ virus infection. Am J Gastroenterol 1996; 91: 1480-1481

53 Kawaguchi T, Nagao $Y$, Tanaka K, Ide T, Harada M, Kumashiro R, Sata M. Causal relationship between hepatitis $C$ virus core and the development of type 2 diabetes mellitus in a hepatitis $\mathrm{C}$ virus hyperendemic area: a pilot study. Int J Mol Med 2005; 16: 109-114

54 Allison ME, Wreghitt T, Palmer CR, Alexander GJ. Evidence for a link between hepatitis $C$ virus infection and diabetes mellitus in a cirrhotic population. J Hepatol 1994; 21: 1135-1139

55 Caronia S, Taylor K, Pagliaro L, Carr C, Palazzo U, Petrik J, O' Rahilly S, Shore S, Tom BD, Alexander GJ. Further evidence for an association between non-insulin-dependent diabetes mellitus and chronic hepatitis $C$ virus infection. Hepatology 1999; 30: 1059-1063

56 Zein NN, Abdulkarim AS, Wiesner RH, Egan KS, Persing DH Prevalence of diabetes mellitus in patients with end-stage liver cirrhosis due to hepatitis $\mathrm{C}$, alcohol, or cholestatic disease. J Hepatol 2000; 32: 209-217

57 Antonelli A, Ferri C, Fallahi P, Sebastiani M, Nesti C, Barani L, Barale R, Ferrannini E. Type 2 diabetes in hepatitis C-related mixed cryoglobulinaemia patients. Rheumatology (Oxford) 2004 43: $238-240$

58 Lecube A, Hernández C, Genescà J, Simó R. Proinflammatory cytokines, insulin resistance, and insulin secretion in chronic hepatitis C patients: A case-control study. Diabetes Care 2006; 29: 1096-1101

59 Soresi M, Carroccio A, Bonfissuto G, Agate V, Magliarisi C, Aragona F, Levrero M, Notarbartolo A, Montalto G. Ultrasound detection of abdominal lymphadenomegaly in subjects with hepatitis $C$ virus infection and persistently normal transaminases: a predictive index of liver histology severity. J Hepatol 1998; 28: 544-549

60 Dammacco F, Sansonno D, Piccoli C, Racanelli V, D'Amore FP, Lauletta G. The lymphoid system in hepatitis $C$ virus infection: autoimmunity, mixed cryoglobulinemia, and Overt B-cell malignancy. Semin Liver Dis 2000; 20: 143-157

61 Zuckerman E, Zuckerman T, Levine AM, Douer D, Gutekunst K, Mizokami M, Qian DG, Velankar M, Nathwani BN, Fong 
TL. Hepatitis C virus infection in patients with B-cell nonHodgkin lymphoma. Ann Intern Med 1997; 127: 423-428

62 Hausfater P, Cacoub P, Rosenthal E, Bernard N, LoustaudRatti V, Le Lostec Z, Laurichesse H, Turpin F, Ouzan D, Grasset D, Perrone C, Cabrol MP, Piette JC. Hepatitis C virus infection and lymphoproliferative diseases in France: a national study. The GERMIVIC Group. Am J Hematol 2000; 64: 107-111

63 Gisbert JP, García-Buey L, Pajares JM, Moreno-Otero R. Prevalence of hepatitis C virus infection in B-cell nonHodgkin's lymphoma: systematic review and meta-analysis. Gastroenterology 2003; 125: 1723-1732

64 Monti G, Pioltelli P, Saccardo F, Campanini M, Candela M, Cavallero G, De Vita S, Ferri C, Mazzaro C, Migliaresi S, Ossi E, Pietrogrande M, Gabrielli A, Galli M, Invernizzi F. Incidence and characteristics of non-Hodgkin lymphomas in a multicenter case file of patients with hepatitis $C$ virus-related symptomatic mixed cryoglobulinemias. Arch Intern Med 2005; 165: 101-105

65 De Re V, De Vita S, Marzotto A, Rupolo M, Gloghini A, Pivetta B, Gasparotto D, Carbone A, Boiocchi M. Sequence analysis of the immunoglobulin antigen receptor of hepatitis $C$ virus-associated non-Hodgkin lymphomas suggests that the malignant cells are derived from the rheumatoid factorproducing cells that occur mainly in type II cryoglobulinemia. Blood 2000; 96: 3578-3584

66 Vallat L, Benhamou Y, Gutierrez M, Ghillani P, Hercher C, Thibault V, Charlotte F, Piette JC, Poynard T, Merle-Béral H, Davi F, Cacoub P. Clonal B cell populations in the blood and liver of patients with chronic hepatitis $C$ virus infection. Arthritis Rheum 2004; 50: 3668-3678

67 Ferri C, La Civita L, Monti M, Giannini C, Cecchetti R, Caracciolo F, Longombardo G, Lombardini F, Zignego AL. Chronic hepatitis C and B-cell non-Hodgkin's lymphoma. QJM 1996; 89: 117-122

68 Matsuo K, Kusano A, Sugumar A, Nakamura S, Tajima K, Mueller NE. Effect of hepatitis $C$ virus infection on the risk of non-Hodgkin's lymphoma: a meta-analysis of epidemiological studies. Cancer Sci 2004; 95: 745-752

69 McColl MD, Singer IO, Tait RC, McNeil IR, Cumming RL, Hogg RB. The role of hepatitis $C$ virus in the aetiology of nonHodgkins lymphoma--a regional association? Leuk Lymphoma 1997; 26: 127-130

70 Ueda T, Ohta K, Suzuki N, Yamaguchi M, Hirai K, Horiuchi T, Watanabe J, Miyamoto T, Ito K. Idiopathic pulmonary fibrosis and high prevalence of serum antibodies to hepatitis $C$ virus. Am Rev Respir Dis 1992; 146: 266-268

71 Arase Y, Ikeda K, Suzuki F, Suzuki Y, Saitoh S, Kobayashi M, Akuta N, Someya T, Hosaka T, Sezaki H, Kobayashi M, Kumada $\mathrm{H}$. Usefulness of the serum KL-6 assay in patients with hepatitis $C$ virus. Intervirology 2005; 48: 400-404

72 Ferri C, La Civita L, Fazzi P, Solfanelli S, Lombardini F, Begliomini E, Monti M, Longombardo G, Pasero G, Zignego AL. Interstitial lung fibrosis and rheumatic disorders in patients with hepatitis C virus infection. Br J Rheumatol 1997; 36: 360-365

73 Clifford BD, Donahue D, Smith L, Cable E, Luttig B, Manns M, Bonkovsky HL. High prevalence of serological markers of autoimmunity in patients with chronic hepatitis C. Hepatology 1995; 21: 613-619

74 Lamprecht $\mathbf{P}$, Ahmadi-Simab K, Gross WL, Hellmich B. [Rheumatology -- Part 3. Research news concerning epidemiology, diagnosis, and therapy of primary systemic vasculitides]. Med Klin (Munich) 2006; 101: 212-225

75 Wu YY, Hsu TC, Chen TY, Liu TC, Liu GY, Lee YJ, Tsay GJ. Proteinase 3 and dihydrolipoamide dehydrogenase (E3) are major autoantigens in hepatitis $\mathrm{C}$ virus (HCV) infection. Clin Exp Immunol 2002; 128: 347-352

76 Lamprecht P, Gutzeit O, Csernok E, Gause A, Longombardo G, Zignego AL, Gross WL, Ferri C. Prevalence of ANCA in mixed cryoglobulinemia and chronic hepatitis $\mathrm{C}$ virus infection. Clin Exp Rheumatol 2003; 21: S89-S94

77 Prieto J, Yuste JR, Beloqui O, Civeira MP, Riezu JI, Aguirre
B, Sangro B. Anticardiolipin antibodies in chronic hepatitis C: implication of hepatitis $C$ virus as the cause of the antiphospholipid syndrome. Hepatology 1996; 23: 199-204

78 Cacoub P, Musset L, Amoura Z, Guilani P, Chabre H, Lunel F, Poynard T, Opolon P, Piette JC. Anticardiolipin, anti-beta2glycoprotein I, and antinucleosome antibodies in hepatitis C virus infection and mixed cryoglobulinemia. Multivirc Group. J Rheumatol 1997; 24: 2139-2144

79 Ordi-Ros J, Villarreal J, Monegal F, Sauleda S, Esteban I, Vilardell M. Anticardiolipin antibodies in patients with chronic hepatitis $C$ virus infection: characterization in relation to antiphospholipid syndrome. Clin Diagn Lab Immunol 2000; 7 241-244

80 Stroffolini T, Colloredo G, Gaeta GB, Sonzogni A, Angeletti S, Marignani M, Pasquale G, Venezia G, Craxì A, Almasio P. Does an 'autoimmune' profile affect the clinical profile of chronic hepatitis C? An Italian multicentre survey. J Viral Hepat 2004; 11: 257-262

81 Nagamine T, Ohtuka T, Takehara K, Arai T, Takagi H, Mori M. Thrombocytopenia associated with hepatitis $C$ viral infection. J Hepatol 1996; 24: 135-140

82 Karasu Z, Tekin F, Ersoz G, Gunsar F, Batur Y, Ilter T, Akarca US. Liver fibrosis is associated with decreased peripheral platelet count in patients with chronic hepatitis B and C. Dig Dis Sci 2007; 52: 1535-1539

83 Jiang $\mathrm{XH}, \mathrm{Xie} Y \mathrm{~T}$, Tan DM. [Study on the influencing factors of thrombocytopenia in viral hepatitis]. Zhonghua Ganzangbing Zazhi 2004; 12: 734-736

84 Giannini E, Borro $\mathrm{P}$, Botta F, Fumagalli $\mathrm{A}$, Malfatti F, Podestà E, Romagnoli P, Testa E, Chiarbonello B, Polegato S, Mamone M, Testa R. Serum thrombopoietin levels are linked to liver function in untreated patients with hepatitis $C$ virus-related chronic hepatitis. J Hepatol 2002; 37: 572-577

85 de Almeida AJ, Campos-de-Magalhães M, de Melo Marçal OP, Brandão-Mello CE, Okawa MY, de Oliveira RV, do Espírito-Santo MP, Yoshida CF, Lampe E. Hepatitis C virusassociated thrombocytopenia: a controlled prospective, virological study. Ann Hematol 2004; 83: 434-440

86 Doi T, Homma H, Mezawa S, Kato J, Kogawa K, Sakamaki $\mathrm{S}$, Niitsu Y. Mechanisms for increment of platelet associated IgG and platelet surface IgG and their implications in immune thrombocytopenia associated with chronic viral liver disease. Hepatol Res 2002; 24: 23

87 Iga D, Tomimatsu M, Endo H, Ohkawa S, Yamada O. Improvement of thrombocytopenia with disappearance of HCV RNA in patients treated by interferon-alpha therapy: possible etiology of $\mathrm{HCV}$-associated immune thrombocytopenia. Eur J Haematol 2005; 75: 417-423

88 Dalgard O, Bjøro K, Hellum K, Myrvang B, Bjøro T, Haug $\mathrm{E}$, Bell $\mathrm{H}$. Thyroid dysfunction during treatment of chronic hepatitis $C$ with interferon alpha: no association with either interferon dosage or efficacy of therapy. J Intern Med 2002; 251: 400-406

89 Kee KM, Lee CM, Wang JH, Tung HD, Changchien CS, Lu $\mathrm{SN}$, Wang PW. Thyroid dysfunction in patients with chronic hepatitis $C$ receiving a combined therapy of interferon and ribavirin: incidence, associated factors and prognosis. $J$ Gastroenterol Hepatol 2006; 21: 319-326

90 Jelev D, Antonov K, Krastev Z. Thyroid disorders after treatment with IFN in patients with chronic viral hepatitis. Bulgarian J Hepatogasroenterol 2005; VII: 45-50

91 Koike K, Moriya K, Ishibashi K, Yotsuyanagi H, Shintani Y, Fujie H, Kurokawa K, Matsuura Y, Miyamura T. Sialadenitis histologically resembling Sjogren syndrome in mice transgenic for hepatitis C virus envelope genes. Proc Natl Acad Sci USA 1997; 94: 233-236

92 Nagao Y, Sata M, Tanikawa K, Itoh K, Kameyama T. Lichen planus and hepatitis $C$ virus in the northern Kyushu region of Japan. Eur J Clin Invest 1995; 25: 910-914

93 Gandolfo S, Carrozzo M. Lichen planus and hepatitis C virus infection. Minerva Gastroenterol Dietol 2002; 48: 89

94 Carrozzo M, Brancatello F, Dametto E, Arduino P, Pentenero M, Rendine S, Porter SR, Lodi G, Scully C, Gandolfo S. 
Hepatitis C virus-associated oral lichen planus: is the geographical heterogeneity related to HLA-DR6? J Oral Pathol Med 2005; 34: 204-208

95 Tucker SC, Coulson IH. Lichen planus is not associated with hepatitis $C$ virus infection in patients from north west England. Acta Derm Venereol 1999; 79: 378-379

96 Pilli M, Penna A, Zerbini A, Vescovi P, Manfredi M, Negro F, Carrozzo M, Mori C, Giuberti T, Ferrari C, Missale G. Oral lichen planus pathogenesis: A role for the $\mathrm{HCV}$-specific cellular immune response. Hepatology 2002; 36: 1446-1452

97 Nagao Y, Sata M, Noguchi S, Seno'o T, Kinoshita M, Kameyama T,
Ueno T. Detection of hepatitis C virus RNA in oral lichen planus and oral cancer tissues. J Oral Pathol Med 2000; 29: 259-266

98 Thornhill MH. Immune mechanisms in oral lichen planus. Acta Odontol Scand 2001; 59: 174-177

99 Lau AH, Thomson AW. Dendritic cells and immune regulation in the liver. Gut 2003; 52: 307-314

100 Sarobe P, Lasarte JJ, Zabaleta A, Arribillaga L, Arina A, Melero I, Borrás-Cuesta F, Prieto J. Hepatitis C virus structural proteins impair dendritic cell maturation and inhibit in vivo induction of cellular immune responses. J Virol 2003; 77: 10862-10871

S- Editor Zhu LH L- Editor Anand BS E- Editor Li HY 